III-1 | 2011

Contemporary Reassessment of William James a Century Later

\title{
The Sign of the Four
}

Italian Pragmatists Retold

\section{Giovanni Maddalena and Giovanni Tuzet}

\section{(2) OpenEdition}

Electronic version

URL: http://journals.openedition.org/ejpap/877

DOI: 10.4000/ejpap.877

ISSN: 2036-4091

\section{Publisher}

Associazione Pragma

Electronic reference

Giovanni Maddalena and Giovanni Tuzet, «The Sign of the Four », European Journal of Pragmatism and American Philosophy [Online], III-1 | 2011, Online since 01 July 2011, connection on 30 April 2019. URL : http://journals.openedition.org/ejpap/877 ; DOI : 10.4000/ejpap.877

This text was automatically generated on 30 April 2019.

\section{c) (†) $९$}

Author retains copyright and grants the European Journal of Pragmatism and American Philosophy right of first publication with the work simultaneously licensed under a Creative Commons AttributionNonCommercial-NoDerivatives 4.0 International License. 


\title{
The Sign of the Four
}

\author{
Italian Pragmatists Retold
}

\author{
Giovanni Maddalena and Giovanni Tuzet
}

\section{AUTHOR'S NOTE}

A previous and partial version of this paper has been published as introduction of Maddalena-Tuzet 2007.

1 Italian pragmatism has been investigated many times by historians of philosophy, but rarely are scholars of Italian pragmatism, both Italian and foreign, actual pragmatists. ${ }^{1}$ That is why it has been so often misinterpreted. Here we want to justify the importance of this small group of people more as representatives of a pragmatist movement than as singular systematic thinkers. This paper aims to be a pragmatist contribution to the study of our four philosophers. A contribution that treats them for what they called themselves: Italian pragmatists. And this makes it possible to see, or at least to glimpse, their "allies and enemies," according to the wording of one of Leonardo's columns, which allows us to expand our vision to the rest of the Italian and international culture of the age.

The center of Italian pragmatism was the periodical Leonardo and the Italian pragmatists are, above all, those who created and edited Leonardo - namely, Papini and Prezzolini and secondly those who joined Leonardo because of their personal friendship with the two young intellectuals and because of philosophical conviction - namely Vailati and Calderoni. Then there are all those who collaborated on Leonardo: Amendola, Regalia, Cecchi, Vacca, Borgese, and many others. We will not concern ourselves with these last only because their participation was not motivated by the study of pragmatism itself, but rather by certain affinities between their ideas and the personalities and tastes of the Leonardians. They were not pragmatism theorists even when they applied it to other fields, such as zoology, literature or mathematics. It would be necessary to carry out a study on them specifically, but it behooves us to focus our attention firstly on those who in some way sought a philosophical formulation of pragmatism. In this sense, Papini, 
Prezzolini, Vailati and Calderoni represent the essence of what we can say about Italian pragmatism.

3 In the first part of the paper, it is necessary to point out that there were, in fact, philosophers who had an original way of thinking and can be grouped together under a single name and a national connotation: the Italian pragmatists. Many scholars, in Italy and abroad, have doubted it, and continue to do so, above all focusing their attention on the thought of Vailati, whose philosophical interpretation is the real watershed for understanding the Italian movement gathered around the Florentine journal. ${ }^{2}$

It is often claimed that Papini and Prezzolini were confused and conceited "brats" and that, instead, Vailati and Calderoni were serious scholars who had truly understood the avant-garde philosophy in America and that they grafted it onto their own already developed studies, thus developing a personal version of it (Garin 1963: 283). If one reads Leonardo and studies the thought of these authors carefully, one realizes that there was among the four men a common matrix, and that this was, in effect, the line of the journal that they, not by chance, proclaimed "the official organ of Italian pragmatism." As a sign of their deliberate and substantial commitment, they founded the Florence Pragmatist Club. It was an attempt to create a non-academic school of philosophical thought (as, after all, Papini had already tried to do with the Vinci group some years earlier) ${ }^{3}$ and it cannot be said that it was simply a sally by young men in search of dramatic gestures. Certainly, Leonardo's season of pragmatism was brief, from 1904 until the final phase of the journal in 1907: that is, from the moment in which the relationship with Vailati and Schiller caused the ideas of Papini and Prezzolini to evolve in a more markedly "pragmatic" sense, abandoning the more generic propositions of the Vinci group (the part of the group most tied to art distanced themselves and founded Hermes). ${ }^{4}$

The critics have often underestimated the simple and double characteristic of being both "pragmatists" and "Italians," which was affirmed by the protagonists of this intellectual adventure. It is said that pragmatism was not involved or that they had not properly understood it; that being Italian did not signal a peculiarity of their philosophy, but rather an accident of the philosophical attitude - neopositivist or scientistic or liberal - of Vailati and Calderoni and of the literary, extravagant and "magical" attitude of Papini and Prezzolini. Of course there are reasons to hold this view; ${ }^{5}$ but we think that the landscape was a little more complicated than the protagonists themselves sometimes were maintaining. The reasons for this strange overlooking of that complexity in the history books can perhaps be traced to the fact that the four men could not easily be ascribed to any of the political or philosophical factions that fought in Italy at the beginning of the xx century and that went

back and forth for the rest of it. When they wrote, the Italian pragmatists were neither positivists nor idealists, and it was not easy to insert them - then or later - among the Catholics or the freemasons, the communists or the fascists, the liberals or the socialists. If we add together this lack of a strong, already consolidated identity to the brevity of the pragmatists' season and to the sporadic nature of their writings, as well as an intrinsic theoretical weakness we will speak about soon, one understands why they were so long forgotten, and why later, when they were rediscovered, a stronger identity was attributed to them a posteriori: as precursors to analytical philosophy or to the philosophy of science or to the action philosophies or to psychology. 
7 What emerges, as we will see in the second part of the paper, is that the Italian pragmatists understood much more about pragmatism than was said. Papini and Prezzolini were young, but they were not unprepared, and their friendship with Vailati helped them greatly to grow and to develop the salient points of the philosophical problems that they perceived. One need only read "Il pragmatismomesso in ordine [Pragmatism put in order]" (L III/2, April 1905), with its famous assertion of the "corridor theory," the "Cronaca pragmatista [Pragmatist chronicle]" (L IV/5, February 1906) where Papini distinguishes three types of pragmatism and the "Introduzione al pragmatismo [Introduction to pragmatism]" (L V/1, February 1907), to realize that what we have before us is not the slapdash aping of a fashionable philosophy. If one looks at the introduction written by Papini, many years later, to the writings of Calderoni and Vailati on pragmatism, ${ }^{6}$ one understands that the awareness of pragmatist ideas and of their importance had not escaped the Florentine writer; one sees instead the signs of a serious understanding and acceptance of pragmatist theory.

In the third part, we will see that there was also a large part of pragmatism that Italian pragmatists did not grasp because they did not know it. But in their misunderstandings they signaled a need and possibly a weakness of the whole pragmatist movement.

9 Finally, by indicating the real gap between them and their American "masters," we will try to explain and assess the standard interpretation that makes them naïve pragmatists. Jaime Nubiola, speaks of "Mediterranean pragmatism," referring to this need to avoid losing the concreteness of the individual in the realization of the universal laws of mathematics and logic, physics and psychology; a need one can find also in Eugenio d'Ors, Unamuno, Bergson, and Schiller.?

\section{Not Just “Brats"}

Papini is recognized, in many ways, as the central figure of Italian pragmatism, albeit there are different interpretations on his character. Leonardo was his creature, as Prezzolini confirmed in a conversation with Mario Quaranta in 1982, shortly before he died. ${ }^{8}$ In the first issues, Prezzolini limited himself to participating with editorials and other writings. Later he would work side by side with Papini as an editor, also lending a hand with financial management. It was in any event Papini who decided the main direction the journal would take. The different programs of Leonardo were his, from the first ones in 1903 (n. 1-3) to those which made explicit the pragmatist positions with the particular meaning given to them by the Leonardians and finally to those of the final years that were open to occultism. His exuberant personality was the intellectual and emotional heart of Leonardo. Papini decided the cover graphics with the innovative drawings by De Carolis and the use of pen names - the famous Gian Falco (Papini) and Giuliano il Sofista [Julian the Sophist] (Prezzolini). He sent Prezzolini to France to meet Bergson, and then went himself to meet him, later reporting in Leonardo the great French philosopher's positions - not without a personal slant and, at times, even a completely personal, voluntary "misrepresentation." At the same time, he used the content of the journal to address psychological problems that brought him closer to James's ideas. ${ }^{10}$ In the first years of the xx century, after all, the reception of pragmatism in Italy coincided with that of James, even if the reverse is not true. ${ }^{11}$ Papini and the other Italian pragmatists had a meeting with James during the 5th International Congress of Psychology, held in Rome in 1905: the American philosopher left the meeting enchanted 
by the Florentine writer's personality. ${ }^{12}$ It was Papini who became friend with Vailati and subsequently established a significant epistolary relationship with Miguel de Unamuno, who recognized him as a privileged interlocutor and was an attentive reader of Leonardo. It was also Papini who wanted to give to the occultists the possibility of expressing themselves in the columns of the Florentine journal, and in the end, he was the one who decided to close the journal down.

11 Papini was not only the "brat" who in the end showed himself to be a conformist, stigmatized by Garin; his thirst to find "a reason to live" was able first to rally the young people of the Vinci group, and later to charm a protagonist of the cultural scene of the time like James and a logician of the caliber of Vailati, who would remain bound to him in a deep, personal friendship full of respect. Certainly, his assertions were often off-key and were negatively affected by his image because of his youth and time. Papini, however, was aware of having particular gifts and was convinced he wanted to fight against a world burdened by affectations and academic formality, bereft of any value for one searching for a reason to live.

12 Prezzolini was just as witty and a more subtle polemicist than his friend. Perhaps he did not have the same instinctive philosophical consciousness as Papini, but he followed the impetus of it. It was Prezzolini who went to meet Bergson and maintained a relationship with F. C. S. Schiller, the English pragmatist. From his articles on Bergson and Schiller as from his debate with Calderoni (from L II/3 November 1904 to LIII/2 April 1905) emerges the stature of a true thinker who not by chance would contribute to the discovery of authors and themes that otherwise would have remained unknown to the Italian public.

13 Suspicions of connections between the pragmatists and fascism have often fed the critical studies, especially American ones, and were centered on Prezzolini. ${ }^{13}$ It is an accusation that one also finds in De Waal's book (2004) but which is difficult to document, excepting a generic observation by Mussolini and a problematic genealogy of fascist thought in La Voce. The accusation seems, in reality, unfounded: Leonardo's season ended in 1907 and Italian pragmatist thought, with its bold individualism and its problems connected with meaning, methodology and psychology, provides very few theoretical pretexts for fascism, unless one considers the generic call to action, which, however, is associated with almost all the cultural expressions of the beginning of the twentieth century. Finally, not even the dates favor this interpretation: when there were the pragmatists, fascism did not exist yet and when there was fascism, the pragmatists were not around anymore, either because they were dead or because they had completely changed their cultural affiliations.

14 Vailati, who died in 1909, was much older than his two Florentine friends: he was 40 years old when the other two, both 22, started Leonardo. He belonged to the school of Peano, with whom he had collaborated on writing Il Formulario, one of the works that were fundamental for the birth of mathematical logic, and he had already taught three History of Mechanics courses at the University of Torino. He was current, and he kept himself current, on everything published in Europe in the fields of his interest, which expanded progressively from mathematics to the history of science, from comparisons of the various sciences to the philosophical method. The results of this activity, which would be rediscovered decades later, can be compared, at least in extent and spirit besides certain assonances in the direction of his thought, to those of Charles S. Peirce. The friendship between Papini and Vailati, whose theoretical motives were so crucial, is perhaps the secret of Leonardo. ${ }^{14}$ The great logician educated Papini in the truest sense of the word; he 
drew out of the magma of Papinian needs a minimum of philosophical and critical structure without substituting his own ideas to those of his friend, for whom he always had respect and admiration. Vailati commented on Papini's work in every issue of Leonardo, correcting, reproaching, but always trying to underline the direction which would keep Leonardo both disruptive and precise at the same time. Papini, as we know, did not always follow Vailati's suggestions, but this does not mean that he was not influenced by the teachings of his friend and mentor. Vailati's stay in Florence from 1904 to 1905, due to his nomination by the Academy of the Lincei to coordinate the national edition of Torricelli's works, is perhaps the most interesting period of Leonardo, when foreign authors met and conversed with Italians and among themselves. It was here that Papini's plans for a true culture outside academia found most success.

Calderoni was the only true student of Vailati. Born in Ferrara, he graduated in law at Pisa in 1901, with a thesis on positive science and criminal law, where he had already expounded his thoughts on the themes of personal responsibility, voluntariness in action, and the role of belief in determining voluntary actions. These themes, elaborate and precise, would return in his later reflections, influenced by Vailati and inspired by pragmatism, and bound in particular to Peirce's pragmatic maxim; Calderoni in fact maintained that voluntary action is that which can be modified by the beliefs that foresee the effects of it. It would be Calderoni who led Leonardo, with the writings "Le varietà del Pragmatismo [The varieties of pragmatism]" (L II/3, November 1904) and "Variazioni sul Pragmatismo [Variations on pragmatism]" (L III/1, February 1905), to the discussion with Prezzolini about the meaning or meanings to be given to the term "pragmatism." But it was not only with pragmatism that Calderoni occupied himself: he wrote about psychology, epistemology, the theory of perception, law, politics, morality, economics; in short, he focused on empirical and social sciences, as much on theoretical issues as on practical. ${ }^{15}$ It can be said that among the Italian protagonists, he was the one who, strong in the methodological lessons learned from Peirce and Vailati and his law studies, tried to extend pragmatism and its methods to the social sciences. Indeed, his most important and well-known work, "Disarmonie economiche e disarmonie morali [Economic disharmonies and moral disharmonies]," published in 1906, tries to apply certain principles and acquisitions of political economics to ethics. Whether his way of treating the themes of ethics and normativity was satisfactory is, however, dubious, but the originality of his attempt is undisputed and did not fail to arouse heated debates (engaged in by Croce, among others). With his mentor Vailati, Calderoni also wrote essays of notable acumen and clarity, such as "Le origini e l'idea fondamentale del Pragmatismo [The origins and fundamental idea of pragmatism]" and "Il Pragmatismo e ivarimodi di non dirniente [Pragmatism and Various Ways of Saying Nothing]," but a premature death in 1914 hindered him from bringing to fruition and articulating in the best way his many provocative ideas that were already influencing the whole Italian cultural environment. ${ }^{16}$

\section{What Did the Italian Pragmatists Understand of American Pragmatism?}

Perhaps we should note the differences because the cliché of the critics, sometimes with very different connotations and slants, is that Papini and Prezzolini understood very little, borrowing only a few confused concepts from James, while Vailati and Calderoni had grasped the essence of pragmatism, albeit only in the Peircean sense. However, we 
think that, their strong differences aside, the four men shared the same understanding of pragmatism. Therefore, putting aside their individual philosophies, we want to see what aspects of original pragmatism might have emerged to the eyes of a Leonardo reader.

At first glance, it seems that very little remains of American pragmatism. The Italian pragmatists mixed pragmatism with Nietzsche and Schopenhauer, with Saint Teresa and Pascal, with Kierkegaard and the occultists. On the other hand, in Leonardo one reads essays on Russell and Poincaré, Pikler and Duhem, Brentano and Juvalta. Each author, taken singly, could be said to have a connection with pragmatism, but all together they seem truly far from an organic whole.

In addition, there was a limited understanding of the subtle distinctions between James and Peirce and, even less, of the single systems of the one and the other. The pragmatism they knew about seems more composed of slogans than of reasoning. Citations of Peirce's pragmatic maxim appear continuously, with all the misinterpretations of utilitarianism and arbitrariness that it had already aroused in the United States. Then there is Vailati's critique of "What is Pragmatism?," Peirce's article published in "The Monist" in April of 1905. Leonardo published James's "La concezione della coscienza [The conception of consciousness]" from the conference in Rome (L III/3, June-August 1905), his "Le energie degli uomini [The energies of men]" (L III/I, February 1905) and various reviews. James is much more present than Peirce, but in his case as well one finds in Leonardo all the classic impressions due to the doctrine of the "will to believe," an "unlucky" title according to James himself (James 1967: 457), as it inspired an infinite number of misunderstandings and misinterpretations. Dewey is cited five times and Lady Welby twice. Instead, appearing many times are Bergson, with whom Prezzolini had a constant and personal relationship, Schiller and Unamuno, the latter a bit forcedly but significantly counted among the pragmatists. The richness of these last relationships brings to mind the possibility of identifying a common matrix, if one exists, of the European or "Mediterranean" version of pragmatism, and gives an idea of the vast "pragmatist" frequentation that a Leonardo reader was able to have. It could be said, in short, that, as much as extension, Leonardo provided unique knowledge for its time.

As for depth of understanding, the tools were insufficient if one wanted to understand the Jamesian system and even more so, the Peircean. This weakness was not a small one: if the Italian pragmatists were not unfaithful in reporting and working out what they knew, they still did not grasp some of the deeper provocations found in the works of the American masters and simply missed, at times, the connection between the novelty of pragmatism and the historical antecedents which the American pragmatists thought they were connecting with. They defined personal historical antecedents but this was the cause of the majority of the misunderstandings by the critics and there often was not a philosophical horizon wider and deeper around which to place the problems that they treated.

The decisive element, however, is that, even though the previous observations remain true (noted by all critics, then and now) the Leonardians grasped the essence of pragmatism much more than the majority of their critics admits. There is one point that unites the apparently distant philosophies of Peirce and James: anticartesianism, the rejection of rationalism as much as empiricism, seen as an impoverishment of the richness of experience ${ }^{17}$ (see the critique of Descartes in the issue dated 27 January 1903: "Criticism of the world is, in him, a preliminary step and nothing more"). From this point of view the articles "I dispregiatori del pragmatismo [The disparagers of pragmatism]" (L 
III/4, October-December 1905) and "Cronaca pragmatista [Pragmatist Chronicle]" (L IV/5, February 1906) are essential; there were certainly differences between the Italian pragmatists, but they were all sure of one thing: the necessity of starting from experience as it is.

The pragmatist sees the world as a collection of facts to which he gives a neutral collective name: for example 'things,' without saying if it is spirit, matter, or something similar. Standing before this world, he says: I observe that certain classes of things change when certain others change. Among the others there is a certain class of things that I will call beliefs, and when they change also change certain other things to which they refer. And that's it! (L IV/5, February 1906)

Jamesian psychology and Peircean logic reject the vision of an inquiry starting from methodic doubt. The only doubt is the living one - according to Peirce - the one that relieves an intellectual and moral uneasiness and dissatisfaction that must be overcome. It is useless to pretend to doubt things that we do not doubt at all, in order to then recover them with a chain of reasoning starting from an empirical or rational primum that one must postulate a priori in order to then construct a chain of reasoning from it. Such a chain will only be as strong - not very - as its weakest link (W2: 212-7). Human reason, on the contrary, starts from a given experience, about which it is certain, and which can be shaken by events and by theoretical and practical problems, but which must be recovered. Reasoning that departs from such an experience does not resemble a chain, but rather a rope, whose strength is due to the sum and the braiding of its threads. This simple observation often escaped the critics, not least because it could not be included in these terms by the protagonists of Leonardo, who, as far as we know, did not know the first "pragmatist" document, the "anticartesian" series that Peirce published in the "Journal of Speculative Philosophy" between 1868 and 1869, where the anticartesian nucleus of his thought was affirmed (W2: 193-241). The one with the deepest awareness of the value of experience was Vailati, who in psychology saw the trait d'union between the refined theory of scientific discovery that Peirce followed and the will to believe that aroused enthusiasm in the followers of James, and compares the various sciences, physical and moral, to them - trying to show the internal structure of this "rope" that is reasoning. Vailati understood the typical characteristics of experience intended in a pragmatist way. As a matter of fact, in contrast to any pre-analytical standard, Vailati held a historical view of truth.

The scholar who will not care about anything but the actual state of his science, as far as competence to judge the importance that actual research or evidence processes (that are now competing) can reach, is in a position similar to a geometer who would like to determine the trend of a curve knowing only one point or one linear element of it. (S2: 6)

Vailati's understanding of the evolutionistic turn of philosophy was as deep as his firm holding an absolute normative value of truth. Truth is in evolution because human theories change, but their changing is not an evidence for relativism but a progressive attunement with reality. Peirce would have said: an attunement that would be reached in the long run of inquiry. Vailati commented this idea in his letter to Papini written on the 22nd of July 1903:

If I did not fear to adventure into the regions of metaphysics and to scandalize you too much, I would say that not only truths exist [...] independently from human opinions (of whomever), but that they are the only things that exist in that way (i.e., to believe that a body exists is equivalent to believe that some expectative 
would be satisfied [...] if we had it, and it seems to me that it does not imply anything else). "Reality" is only another name for "truth." (Vailati 1971: 362) ancient adaequatiorei et intellectus; a new way which is formally different as substantially close to the Aristotelian or Thomistic version. Still, this formulation stresses the importance of evolution, and therefore the event of truth. Truth is something that happens to an idea, as James would have said. This is why Vailati's view cannot be equated with any analytic or empiricist pattern: sense and meaning of a term or of a proposition can never be saturated before the end of inquiry. The concept of truth is so wide to avoid both rationalism and empiricism and it brings a radical critique of any form of reductionism, in particular of the ontologization of analytic propositions (S1: 130-33). There are no a priori necessary truths: truth would be accomplished in the conditional future of experience.

This version of truth definitely overtakes any dichotomy between ideas and facts, as far as both evolve and can change reality up to the perfect attunement of the long run.

[...] this world of paper to which Galileo despised so much, the world of ideas and human imagination, is neither less real nor less sensitive nor worth studying or intelligent observing than the other world to which he dedicated his mind with so great success. Opinions, whether true or false, are always facts, and as facts they deserve and claim to be object of inquiry, tests, and explanation exactly as any other order of facts. And with the same end: through their varieties, through their complex structure and transformation, the end is to determine constant elements, uniformities, and laws to which they ought their dynamics. (S2: 4)

But also Papini, Prezzolini and Calderoni, each in their own way, rejected the idea of the indubitable epistemological primumand because of this, found a theoretical unity in their attack of both positivism and idealism. If they had been able to and had wanted to delve deeper into the writings of Peirce and James, they would have discovered all the phenomenological, semiotical and metaphysical depth that such visions involved, as well as their intrinsic and subtle differences. They attested, instead, to the pragmatic maxim and the "will to believe," they understood them and discussed them: in this lies both their strength and their weakness.

\section{What Did the Italian Pragmatists Add to American Pragmatism?}

Italian pragmatists added to American pragmatism a personalistic existential tone and a nihilist disquiet. See Leonardo n. 2 of 1903 in which Papini asserts: "We will retain a single ambition: complete possession of reality." Or Vailati's letter in which he declares himself fully in agreement with Papini in his need for agreement between thought and action:

Dear Papini,

Upon my return from Bologna, I found your letter in Crema and now here the magnificent issue of Leonardo. Your article "Marta e Maria [Martha and Mary]," especially on page 7, column 2, clarified for me your way of seeing and understanding the philosophy even more wonderfully and energetically than any of your previous writing has done. There are those who have dreamed that which they couldn't achieve and those who have achieved - or made it possible to achieve that which no-one (and they less than others) has ever even dreamed of wanting. Now it is necessary the rising of those who proclaim that "doing" and "being able to do" only have value if they serve to "realize a dream" and that dreams only have

European Journal of Pragmatism and American Philosophy, III-1 | 2011 
value if one may hope to have the strength and means to realize them. The simultaneous recognition of both these two requirements is much more than is needed to give substance and life to a new orientation of the philosophical speculation; this has had and can have no higher scope. (Vailati 1971: 397) experienced in vital particulars. Underlining the importance of the particular and the distinction between particulars as criteria to identify the meaning of statements is a constant characteristic of all the Italian pragmatists. Distinguishing means finding the true particular, vibrating with life, those that unite thought and action, separating them from what is universal and empty or generic or deprived of enough strength to become action. The spirit's "desire to incarnate" which the idealists spoke about and which was especially urgent in Papini can also be found in the others, although in a less marked form. One must consider that this aspect of the person or of the individual was absent from American pragmatism, according to which the person is the result of a complex intersection of forces (physical, mental, intellectual) that move reality and thought and that, from a metaphysical point of view, rest either on different modalities of the same reality (Peirce) ${ }^{18}$ or on ultimate unities of experience that have nothing to do with individual consciousness (James). ${ }^{19}$ In this sense Italian pragmatism modified original pragmatism and involved taking a personal stance that James, much admired by them, pointed out in a letter to Papini saying that the Italian pragmatists had taught him "courage" (James 2003: 214).

oxically, but entirely understandably, together with the emphasis on singularity and concreteness in which life and its general laws vibrate, one finds in the Italian pragmatists a nihilist background, which one notices especially in issue 10 of November 1903 and December 1903: it is the suspicion that life lacks a true reason, a suspicion that pressed them to adhere to pragmatism understood as a reaction of the will to the absurdity of existence. Papini would express it years later with the figurative expression: "I did not approve, I did not accept the universe as it was. My attitude was spiteful and proud, like Capaneo trapped in an earthly hell. And I tended to deny reality, to deny copies of reality, a despise of the rules of real life, and to remake, in my way, a different and more perfect reality" (Papini 1977: 233).

It is a Nietzschean touch that turns up often in the four pragmatists in different ways and that often becomes a simple "relativism," as in the practical realm for Vailati and Calderoni, according to whom each person can choose his own "table of values" and then organize the means to those ends (S2: 91). Behind this vision there is, especially in Papini, a certain reading of Kierkegaard, Schopenhauer, Stirner, Nietzsche, Bergson, in addition to James's Varieties of Religious Experience. There is also, especially in Vailati and Calderoni, a reading of utilitarianism and English liberalism, of Bentham and Mill, but also of the recent political economy. Moreover, from the epistemological point of view, we cannot neglect the ideas treated by Newman and his division between real understanding of the particular and formal understanding of the universal (Newman 1973). Nor can we disregard the influence of Brentano, who was for many years a resident of Florence and 
often visited by the pragmatists, for the distinction between representation, belief and will (Dal Pra 1984). The latter theme, the unity of belief and representation, was the source of Peirce's semiotics in "A New List of Categories," ${ }^{20}$ which unfortunately the Italian pragmatists did not know, and which was the secret root of the unity of experience in Jamesian psychology that cropped up in his philosophical works as well. The fact of not having recognized such a unity, we may suppose, is the true beginning of the end of Leonardo from the theoretical point of view, the reason for which pragmatism was not, in the end, a satisfactory answer for its Italian supporters. Existentialist personalism and nihilism as love of the particular and suspicion of a complete answer mark the peculiarity of Italian pragmatism for good or for bad. Being committed to the comprehension of the particular (in this Newman has a certain importance), in real understanding as opposed to a formal or notional understanding is the reason the Italian pragmatists were so bold in their attempt to know and judge all that was produced in the intellectual sphere. On the other hand, opposition to formal knowledge often resolves itself in nominalism and in a consequent skepticism that at times seems to prevent the possibility of authentic knowledge. In the last issue of the journal, Papini says that the necessity of finding a reason to live is the most important thing to which Leonardo was not able to find the answer. Perhaps because there is no answer?

Here the pragmatists' paths diverged: Prezzolini returned to idealism; Vailati simply stopped, as expressed in "La ricercadell'impossibile [The search for the impossible]" (L III/4, October 1905), maintaining that the search for ultimate causes has the nature of a utopian construct (which he compared to mathematical postulates); Calderoni remained anchored to the impossibility of rationally deliberating on ends and values; Papini would find an answer many years later in incarnation and Catholicism. ${ }^{21}$

The consequences of this type of understanding, personalistic and nihilistic, places before us different personal philosophies: at least in this sense, Papini was right when he said that there was no Italian pragmatism, but Italian pragmatists. Love of the particular, of the solidity of experience and the importance of the act of the will takes on a personal form.

From a practical point of view, this translates into a perennial battle, typically Italian, in a world made up of friends and enemies. For the Italian pragmatists, it was a matter of life and death and, in a certain sense, the end of Leonardo marked their defeat or at least the de- feat of pragmatism as an essential weapon of this battle. Calderoni and Vailati, who felt this existential background less, were more disappointed by it, but even for them pragmatism was a weapon against superficiality and arrogance of thought, especially academic thought. The struggle against the narrowness of positivism and the redundancy of idealist monism are the emblem of this "militant" version of Italian pragmatism, characterized by the "courage" to risk one's ideas and the need to find "allies" among thinkers from all over the world.

\section{What Did the Leonardians Not Understand About Pragmatism? Or Rather, Where Is the Italian Pragmatists' Weakness?}

In their journey from the abstract to the concrete they respected, after all, the epistemological terms of the idealists, as we can see in the editorials of all the first issues 
of Leonardo. "Personalisti e idealisti nel pensiero [Personalists and idealists in thought]" is the definition of the first issue of Leonardo, January 1903); "Un personalismo con fondamenti gnoseo logici [A personalism with gnoseological foundations]" says Papini in the article "Me e non Me [Me and not me]," L I/2, January 1903; overcoming life in the spirit in "Al di là della vita [Beyond life]," L I/7, March 1903; the interior man as the author of mystical creations in "Il segreto di Leonardo [The secret of Leonardo]," L I/8, April 1903). In this case it was Papini who wrote and, given his young age, perhaps idealism was the only tool available to him. Nevertheless, Papini was not the only one to reveal a certain inconsistency between a general philosophical understanding and his epistemological attitudes.

The rationalism and irrationalism that the personalist and nihilist pragmatist of the Leonardians alternated between in the different sectors of philosophical research were not able to dislodge the idealist gnoseological system that both Peircean semiotics and Jamesian psychology questioned. Thus, there is a strong difference between the declarations that bring to light the anticartesian core of pragmatism and the epistemological articulation which often refers to the same masters of their "enemies": to Locke and Hume on one hand, and to Berkeley and Schopenhauer (through whom Kant, whom they often criticized, reappears) on the other. It is interesting that Papini, in an article in one of the first issues of Leonardo ("La favola del Sole e dell'Unico [The Fable of the Sun and the Only One]," L I/9, May 1903) says that monism is in the will but not in the act, that the world is not God, but is becoming God. Perhaps Vailati and Calderoni could not completely share an assertion of this kind, but their decision not to take a position on the ends that each one chose voluntarily remains in strong contrast, if not in contradiction, to methodological pragmatism. In this context, it is useful to recall that Vailati thought that deduction was the real tool of inquiry and he conceived it in such a way to imply the pragmatic turn that any conditional formula includes. But in this way Vailati had to accept that the principles from which we draw conditionals are postulates, chosen according to an arbitrary will. Peirce, his pretended American partner, hold a very different idea, building a complete relationship between reality and our reasoning both from an epistemic point of view - where abduction and its phenomenological, aesthetic and ethic foundations play a decisive role - and from a metaphysical point of view - where metaphysical realism is an essential part of the path of knowledge.

But also James would have never accepted an ultimate disembodied view of freedom. Freedom is always an attitude toward reality and it is intertwined with the whole psychological stream of thought. This continuity between reality and thought, that Dewey later articulated in his Logic, is the epistemic-metaphysical matrix of the "rope" of experience. And Italian pragmatists never grasped it.

A gap remains between the choice of the means and the choice of the ends, which Papini and Prezzolini resolved with the doctrine of the Man-god, Vailati and Calderoni with ethical relativism. In this way they left space for monism, whether idealist or nihilist, which they wanted to oppose. From this point of view, the parabola of Prezzolini's thought returning to Crocean idealism is very significant.

Such a gap between the general intention of their philosophies and the epistemologies they could display - weak epistemologies in which there is a methodological abysm between the choice of means and the choice of ends - could therefore be generalized by saying that the Italian pragmatists lacked that which they sought: the synthesis of experience, which they saw, lived and wanted to penetrate - or "possess," to use Papini's 
term - both in extension and in intension ("the intellectual empire of all the beings in the universe" says Papini in the first issue of Leonardo). They claimed that they wanted to know this synthesis or deep connection (especially Papini in the initial phase and in the occultist phase of Leonardo) and, at the same time, did not want it (the mystery is the sun that bewitches and blinds in "La favola del Sole e dell'Unico [The Fable of the Sun and the Only One]," L I/9, May 1903) or that they did not want to occupy themselves with problems that concern spheres where consciousness cannot go (Vailati). In the end, this uncertainty proved fatal to Leonardo. When Papini wrote that there is no mystery, only the unknown and the unknown is that which is not, he condemned the need to possess that had driven him to a perpetual, empty search, forcing him to experience continual changes and great dissatisfaction. The others were more cautious in their assertions but there still remained in them this tension between a totality towards which reason tends and an epistemology that does not allow one to try to know it and to discuss it. Thus their philosophical attempts remain either incoherent or incomplete.

The theories that the Italian pragmatists worked out were not ever as significant as their theoretical needs and their philosophical taste thanks to which they brought an important philosophical theory to Italy and introduced their readers to the real problems of the philosophy of their time. One can say that, after all, they violated the most basic rule of knowing, which Peirce had summed up with the phrase: "Do not block the way of inquiry." Papini blocked it in intensity, Vailati in extension, Prezzolini and Calderoni followed their friends and mentors, but the search never went so far as to fully confront the enigma of experience, the profound connection between thought and the reality of which it is a part.

\section{BIBLIOGRAPHY}

AQUECI F., (1999), "Vailati, il linguaggio e il valore civile del retto ragionare," in Lezioni su Giovanni Vailati, Crema, Leva Artigrafiche, 21-38.

ALIOTTA A., (1902), “Il radical empirismo di W. James," Medusa, Febbraio.

ALIOTTA A., (1940), Le origini dell'irrazionalismo contemporaneo, Napoli, Libreria Scienti- fica Editrice.

ALIOTTA A., (1949), Il problema di Dio e il nuovo pluralismo, Roma, Perrella.

ARRIGHI C., CANTÙ P., DE ZAN M. \& P. SUPPES, (eds.), (2010), Logic and Pragmatism. Selected Essays by Giovanni Vailati, Stanford, CSLI.

BARONE F., (1963), "Vailati e l'analisi del linguaggio," Rivista Critica di Storia della Filosofia, 18, 1963/3, 374-86.

BORSELLINO P., (1979), "Libertà, giustificazione della pena e metodo delle discipline penali in Calderoni," Rivista Critica di Storia della Filosofia, XXXIV/3, 316-48.

BRODBECK M., (1963), “Vailati's Implicit Ontology,” Rivista Critica di Storia della Filosofia, 18, 1963/3, $332-7$. 
CALDERONI M., (1924), Scritti di Mario Calderoni, ed. by O. Campa, 2 vols., Firenze, La Voce.

CALDERONI M. \& G. VAILATI, (1918), Il pragmatismo, Lanciano, Carrabba.

CECCHINEL S., (1963), "I tropi della logica e la semeiotica generale di Vailati," Rivista Critica di Storia della Filosofia, 18, 1963/3, 387-98.

COlAPIETRo V., (1994), “'Tell Your Friend Giuliano...': Jamesian Enthusiasms and Peircean Reservations," Transactions of the Charles S. Peirce Society, XXX (4), Fall, 897-926.

Colella E. P., (1994), “Two Faces of Italian Pragmatism: The Prezzolini-Calderoni Debate, 1904-1905," Transactions of the Charles S. Peirce Society, XXX (4), Fall, 861-96.

DAL PRA M., (1984), Studi sul pragmatismo italiano, Napoli, Bibliopolis.

DE WAAL C., (2004), On Pragmatism, Belmont, Wadsworth.

FACCHI P., (1952), "I contributi di G. Vailati alla metodologia e all'analisi del linguaggio," Rivista Critica di Storia della Filosofia, 7, 41-8.

FERRARI M., (2006), Non solo idealismo. Filosofi e filosofie in Italia tra Ottocento e Novecento, Firenze, Le lettere.

GARIN E., (1963), “G. Vailati nella cultura italiana del suo tempo," Rivista Critica di Storia della

Filosofia, 18, 1963/3, 275-93.

GARIN E., (1966), Cronache di filosofia italiana 1890/1943, Roma-Bari, Laterza.

Geymonat L., (1963), “Alcune considerazioni sull'interesse di Vailati per la logica," Rivista Critica di Storia della Filosofia, 18, 1963/3, 410-5.

GULlACE G., (1962), “The Pragmatist Movement in Italy,” Journal of the History of Ideas, XXIII/1, 91-105.

HARRIS H. S., (1963), "Logical Pragmatism and the Task of Philosophy in Peirce e Vailati," RivistaCritica di StoriadellaFilosofia, 18, 1963/3, 311-21.

JAMES W., (1967), The Writings of William James: A Comprehensive Edition, edited by J. McDermott, New York, Random House.

JAMES W., (1975), Pragmatism (1907), Cambridge, Harvard University Press.

JAMES W., (2003), The Correspondence of William James, ed. by I. K. Skrupskelis and E. M. Berkeley, Charlottesville and London, University Press of Virginia.

LANARO G., (1979), "Pragmatismo e positivismo nel pensiero di Calderoni," Rivista Critica di Storia della Filosofia, XXXIV/3, 272-85.

LANARo G., (1980), “Introduzione” to G. Vailati, Scritti filosofici, Firenze, La Nuova Italia, 5-31.

MADDALENA G. \& G. TUZET, (eds.), (2007), I pragmatisti italiani. Tra alleati e nemici, Milano, Alboversorio.

MARCUCCI S., (1958), “Il pensiero di G. Vailati," Filosofia, 19, 1958/2, 260-301.

MARINOTTI A., (1997), "La ricezione di Bergson in Italia attraverso il 'Leonardo', "Revue des Études Italiennes, N.S. T. XLIII n³-4, Luglio-Dicembre 1977.

MINAZZI F., (2011), Giovanni Vailati epistemologo e maestro, Milano, Mimesis.

MORI M., (1972), "L'interpretazione attivistica di James negli scritti di Papini," Rivista di filosofia, LXIII. 
NEWMAN J. H., (1973), An Essay in Aid of a Grammar of Assent, Westminster, Christian Classics Inc.

PAPINI G., (1977), Opere, Milano, Mondadori.

PAPINI G., (1984), Storia di Cristo, Firenze, Vallecchi.

PAPINI G., (2005), Il non finito. Diario 1900 e scritti inediti giovanili, Firenze, Le lettere.

PARRINI P., (1979), “Analiticità e teoria verificazionale del significato in Calderoni," Rivista Critica di Storia della Filosofia, XXXIV/3, 286-293.

PONTARA G., (1979), “Conoscenza e valutazione: lo scetticismo etico di Calderoni,” Rivista Critica di Storia della Filosofia, XXXIV/3, 349-66.

POZZoNi I., (2004), "Disarmonie economiche e disarmonie morali. L'etica nella riflessione di Mario Calderoni," in Annuario del Centro Studi Giovanni Vailati, anno 2004, 53-88.

Pozzoni I. (ed.), (2009), Cent'anni di Giovanni Vailati, Milano, Liminamentis.

QUARANTA M., (1987), “Letture di Giovanni Vailati nella cultura italiana (1911-1986),” in G. Vailati, Scritti, Bologna, Arnaldo Forni Editore.

QUARANTA M., (2003), "Il programma di ricerca di Giovanni Vailati," in G. Vailati, Gli strumenti della ragione, Padova, Il Poligrafo.

RossI M. M., (1923), “Il pragmatismo italiano,” Rivista di psicologia, XIX, 1923/1, 8-23.

ROSSI LANDI F., (1958), "Materiale per lo studio di Vailati," Rivista Critica di Storia della Filosofia, 1958/1, 82-108.

SANTUCCI A., (1963), Il pragmatismo in Italia, Bologna, il Mulino.

SCHRAM PIGHI L., (1981), "Henri Bergson e la cultura francese nel Leonardo," in Leonardo, vol. 1 (1903-1905), Bologna, Arnaldo Forni.

TORALDO DI FRANCIA M., (1983), Pragmatismo e disarmonie sociali. Il pensiero di Mario Calderoni, Milano, Franco Angeli.

VAILATI G., (1971), Epistolario: 1891-1909, ed. by G. Lanaro, Torino, Einaudi.

VAILATI G., (1980), Scritti filosofici, ed. by G. Lanaro, Firenze, La Nuova Italia.

VAILATI G., (2003), Gli strumenti della ragione, ed. by M. Quaranta, Padova, Il Poligrafo.

VILLA G., (1962), “Sul pragmatismo logico di Vailati e Calderoni: la questione delle varietà del pragmatismo," Memoria I, Memorie dell'Accademia delle Scienze di Bologna, Classe di Scienze morali, serie V, vol. X, 187-213.

VILLA G., (1963), “Alcuni aspetti del pragmatismo di Vailati," Rivista Critica di Storia della Filosofia, $18,1963 / 3,294-310$.

ZAMBELloni F., (1970), “Bergson e la filosofia italiana,” Filosofia, XXI (3), 331-60.

ZANONI C. P., (1979), "Development of logical pragmatism in Italy," Journal of the History of Ideas, XL, 1979/4, 603-19.

\section{APPENDIXES}

Abbreviations 
The Essential Peirce, 2 vols., ed. by the Peirce Edition Project, Indianapolis and Bloomington: Indiana University Press, 1991-1998. The abbreviation is followed by Arabic numerals for volume and page. For example, EP1: 348 .

L

Leonardo. The abbreviation is followed by a Roman numeral for the volume, and Arabic numerals for the issue, date, page. For example, L I/1, January 1903: 1.

$\mathrm{S}$

Scritti of Giovanni Vailati (vol. 1: Scritti di filosofia; vol. 2: Scritti di scienza; vol. 3: Scritti di scienze umane), ed. by M. Quaranta, Bologna: Arnaldo Forni, 1987. The abbreviation is followed by Arabic numerals for volume and page. For example, S1: 34.

W

Writings of Charles Sanders Peirce, 6 vols. published, Bloomington and Indianapolis: Indiana University Press, 1981-2000. The abbreviation is followed by Arabic numerals for volume and page. For example, W2: 49.

\section{NOTES}

1. Among American authors see Colapietro 1994, and De Waal 2004. In Italy the great exception is the wonderful book by Santucci (1963), which has the single defect of being inevitably dated in a field, like that of pragmatism, where studies have advanced immensely in the last forty years thanks to the publication of James and Dewey's Opera Omniaand, above all, thanks to the cataloging and publication (not yet completed) of the Peircean manuscripts. The references for those editions are the classic ones. The writings of John Dewey are published in The Collected Works of John Dewey, 1882-1953, ed. by J. A. Boydston, Carbondale and Edwardsville, Southern Illinois University Press, 1969-91. The main edition of James are The Works of William James, ed. by F. Burkhardt, F. Bowers, I. Skrupskelis, Cambridge (Mass.), Harvard University Press, 1975- and The Correspondence of William James, ed. by I. K. Skrupskelis and E. M. Berkeley, Charlottesville and London, University Press of Virginia, 2003. Peirce's writings are published in C.S. Peirce, Collected Papers of C. S. Peirce, 8 vols., ed. by C. Hartshorne, P. Weiss (vols. 1-6), and A. Burks (vols. 7-8), Cambridge (Mass.), Harvard University Press, 1931-1958; The New Elements of Mathematics, ed. by C. Eisele, The Hague, Mouton Publishers, 1976; The Essential Peirce, 2 vols., ed. by the Peirce Edition Project, Indianapolis and Bloomington, Indiana University Press, 1991-98 (EP). The Peirce Edition Project is working on the complete chronological edition, called Writings of Charles Sanders Peirce, 6 vols published, Bloomington and Indianapolis, Indiana University Press, 1981-2000 (W).

2. This view has been sustained above all by those who tried to treat Vailati as a precursor of the neopositivist thought. Among others is worth recalling Marcucci 1958, Lanaro 1980, Brodbeck 1963, Facchi 1952, Barone 1963, Cecchinel 1963, Geymonat 1963. A second interpretative stream has defended Vailati's pragmatist identity opposing Vailati and Calderoni as followers of Peirce to the others, uncertainly stepping into James' tracks. Among those, with Garin 1963, we have to mention at least Rossi 1923, Gullace 1962, Villa 1962, Zanoni 1979, and more recently De Waal 2007, and - partially - Colapietro 1994. More complicated is the methodological view held by Harris 1963 and Quaranta 2003, in which Vailati is a precursor of methodologies that only now emerge as important. In this Italian pragmatists were originally pragmatists but the only real philosophical contribution came from the great mathematician. Another important book is the 
one written by M. Ferrari (2006) whose interpretation of Vailati is not centered on pragmatism, but on his moral general belonging to European culture. Ferrari's well balanced analysis casts a light on Vailati's debt to Leibniz and to contemporary philosophy of mathematics and science.

3. L III/2, April 1905: 45.

4. Hermes was a periodical founded by Giuseppe Antonio Borgese and Enrico Corradini in 1904. They were interested in literary criticism and the painter Adolfo De Carolis was responsible for the graphical aspect of the periodical. Papini himself collaborated with Hermes in many of the twelve numbers, until the last publication in 1906. As for Papini's Vincian proclamation, see the introduction by G. Luti to the complete edition of Leonardo 1903-07 (Firenze \& Vallecchi 2003). In this volume it is possible to find the transcription of the "Discorsoai Vinciani" [Discourse to Vincians].

5. "Presso di noi il Pragmatismo si divise quasi nettamente in due sezioni: quella che si potrebbe dire del Pragmatismo logico e quella del Pragmatismo psicologico o magico. Alla prima appartenevano Vailati e Calderoni ai quali moltissimo deve - [...] - la teoria della scienza e la logica considerata come studio del significato delle proposizioni e delle teorie. La seconda era composta da me e da Prezzolini e noialtri, spiriti più avventurosi, più paradossali e più mistici svolgemmo soprattutto quelle teorie che ci facevano sperare un'efficacia diretta sul nostro spirito e sulle cose" [In Italy pragmatism was almost exactly splitted in two parts: one that we could call logic pragmatism and the other one that we could call psychologic or magic pragmatism. Vailati and Calderoni - [...] - to whom theory of science and logic intended as studies on meaning of propositions and theories are indebted, belong to the first one. The second one is composed by Prezzolini and me, more adventurous, paradoxical, and mystical kind of men. We developed above all those theories which made us hope for a direct efficacy on our souls and on things] Papini, SulPragmatismo, in Papini (1977: 7).

6. See the introduction to Calderoni-Vailati (1918), written by Giovanni Papini.

7. Many contributions in Maddalena-Tuzet 2007 cover these relationships. On D'Ors and pragmatism see the chapters by M. Torregrosa \& A.González (p. 245-54, 255-72). On the Unamuno-Papini relationship see the contribution by I. Martínez (167-8). About the acquaintance with Bergson and Schiller see the chapter by M. Luisi (179-200) and the Appendix by M. Quaranta (273-85).

8. Interview with Giuseppe Prezzolini by Mario Quaranta, "Quaderni razionalisti," n. 2-3, primavera 1983, 77-84.

9. "Enrico Bergson, come tutti i maestri buoni, non può avere scolari, ma solo lettori amorosi che, appena abbian capito, debbon buttar da parte i suoi libri e sprofondarsi, per conto loro nel fiume dell'intuizione" [Henry Bergson, as any good professor, cannot have students but loving readers who - as soon as they understand - must throw his books and deepen their selves into the river of intuition] (from the introduction written by G. Papini to Bergson (1913: 3-4)). See also Marinotti (1997: 149-78), SchramPighi 1981, Zambelloni (1970: 331-60).

10. Papini writes about his interest in psychology in Papini (2005: 177-8). There are also many articles in Leonardo where Papini and Prezzolini discuss the problem of soul and psychology (L II/2, June 1904: 29; L III/2, April 1905: 41-43; L III/3, June-August 1905: 123-4). See also Garin (1966: 53) and Mori (1972: 213-27).

11. Antonio Aliotta is a perfect example of this problem. He elaborated a deep interpretation of James' psychology, but frequently went beyond James intention. See Aliotta 1902, 1940 and 1949. 12. James (2003: 27-9). See also Colella 1994, and Colapietro 1994.

13. For the doubts on Prezzolini and pragmatism in general see Jacobitti 1981, and the balance made by Colapietro 1994.

14. The theoretical similarity of the two philosophers appears in Leonardo (L IV/5, February 1906: 59-60), but also in some letters that Vailati wrote to Papini (Vailati 1971: 397).

15. See Calderoni 1924, which is a posthumous collection of his major writings. 
16. On his influence on Italian philosophy see in particular Lanaro 1979, Parrini 1979, Borsellino 1979, Pontara 1979, Toraldo di Francia 1983, Pozzoni 2004.

17. See W2: 193-210 and W2: 211-41. See also the conferences James made in Harvard and published in 1907 as Pragmatism: A New Name for Same Old Ways of Thinking (James 1975).

18. EP1: 348-51; EP2: 2-3.

19. See his 1904 and 1905 papers Does "Consciousness" Exist? and The Notion of Consciousness (now in James 1967: 169-83, 184-94).

20. W2: 49-58.

21. See for Papini's conversion the Introduction to his Storia di Cristo (1984: 32-4).

\section{ABSTRACTS}

This paper is a contribution to the study of the four classical Italian pragmatists: Papini, Prezzolini, Vailati and Calderoni. They are seen more as representatives of a pragmatist movement than as singular systematic thinkers. The center of Italian pragmatism was the periodical, Leonardo, where these authors discussed and presented an original and provocative understanding of pragmatist philosophy. Thier understanding of pragmatist philosophy has often been underestimated by the subsequent literature. They showed a good comprehension of the novelty brought by American pragmatism but, ignoring some of the most important epistemic aspects of Peirce's and James's theories, their philosophical proposals often missed consistency. However, even in their misunderstandings, they signaled a need and possibly a weakness of the whole pragmatist movement. Italian pragmatists underlined the importance of the concreteness of individuals in the realization of universal laws of mathematics and logic, physics and psychology. But, this attitude suffered from some serious tensions between metaphysical assumptions and methodological claims.

\section{AUTHORS}

\section{GIOVANNI MADDALENA}

Università del Molise

maddalena[at]unimol.it

\section{GIOVANNI TUZET}

Bocconi University

giovanni.tuzet[at]unibocconi.it 